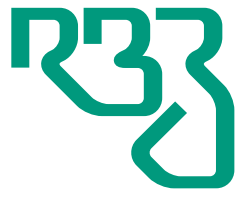

Revista

Brasileira de

Zootecnia

Brazilian Journal of Animal Science

ISSN 1806-9290

www.rbz.org.br

\section{Genetic parameters, genetic trends, and principal component analysis for productive and reproductive traits of Guzera beef cattle}

\author{
Nicole Colucci Tramonte $^{1}$ (iD, Natalia Vinhal Grupioni ${ }^{1}$ (iD, Nedenia Bonvino \\ Stafuzza $^{1}$ iD, Diego Gomes Freire Guidolin ${ }^{2}$ (iD, Rodrigo Pelicioni \\ Savegnago $^{1}$ (D), Luiz Antonio Framartino Bezerra ${ }^{3}$, Raysildo Barbosa Lôbo ${ }^{3,4}$, \\ Danísio Prado Munari ${ }^{*}$ (iD \\ ${ }^{1}$ Universidade Estadual Paulista "Júlio de Mesquita Filho", Faculdade de Ciências Agrárias e \\ Veterinárias, Departamento de Ciências Exatas, Jaboticabal, SP, Brasil. \\ ${ }^{2}$ Universidade Anhanguera, Campo Grande, MS, Brasil. \\ ${ }^{3}$ Universidade de São Paulo, Faculdade de Medicina de Ribeirão Preto, Departamento de \\ Genética, Ribeirão Preto, SP, Brasil. \\ ${ }^{4}$ Associação Nacional de Criadores e Pesquisadores, Ribeirão Preto, SP, Brasil.
}

\begin{abstract}
The objectives of this study were to estimate genetic parameters and genetic trends and perform principal component analysis for the following traits: body weight adjusted at 210 days of age (W210), one year (W365), and yearling or 450 days of age (W450); weight gain from birth to weaning or 210 days of age (WGBW), from weaning to 365 days of age (WGW365), and from one year to yearling (WGY); and scrotal circumference adjusted at 365 (SC365) and 450 (SC450) days of age of Guzera beef cattle. Variance components were estimated under a two-trait animal model using the restricted maximum likelihood method. The fixed effects included in the model were birth season, contemporary group, and covariable age of dam at calving as linear and quadratic effects. Heritability estimates ranged from 0.10 (WGY) to 0.41 (W450 and SC450). The studied traits could be used as selection criteria because of their sufficient additive genetic variability to respond to the selection process. However, lower selection efficiency is expected for WGBW and WGY. Genetic trends studied were significant for all traits, except WGY. The W365 and W450 traits belonged to the "Genetic Merit Total" index and responded to selection with favorable genetic gain per year. The traits that were not included in the selection index showed favorable positive genetic correlations attributed to the indirect selection processes. The principal component analysis identified two groups of traits. The first group related to body weight and weight gain and the second related to the scrotal circumference, indicating that selection could be applied to one group of traits within each observed group. The genetic gains were attributed in the same direction for the other traits belonging to the groups. Thus, we recommend selecting animals for W365 based on first group, and SC365 based on second.
\end{abstract}

Keywords: animal breeding, Bos taurus indicus, genetic correlation, heritability

\title{
Introduction
}

In the genetic constitution of Brazilian cattle, it is estimated that Bos taurus indicus DNA is present in more than $80 \%$ of the herds either as purebreds or crossbreds (IBGE, 2015). The Guzera is considered a dual-purpose breed and has been widely used in both purebred and crossbreeding schemes to produce 
efficient dairy cows and beef calves since they have precocity, adaptability, resistance to parasites, heat tolerance, and good performance (Peixoto et al., 2016).

Productive performance traits, such as body growth and reproductive efficiency, affect the profitability of beef cattle (Laureano et al., 2011), because they decrease the generation interval, accelerate the genetic progress, and result in precocious animals with better performance. Thus, the antagonism that has been observed between the direct and maternal genetic effect estimates and their correlation with growth traits in beef cattle is important for breeding programs, since they allow more accurate heritability estimates (Campêlo et al., 2004).

Animal performance can be evaluated by body weight and weight gain adjusted to different ages, because these traits are easy to measure and present moderate to high magnitudes of heritability estimates, which generally respond satisfactorily to the selection process (Boligon et al., 2010a). Thus, the present investigation aimed to estimate genetic parameters and trends for traits related to productive and reproductive performance of Guzera beef cattle and explore relationships among animal estimated breeding values for these traits using the principal component analysis (PCA) method to provide subsidies for the genetic evaluation program of this economically important breed.

\section{Material and Methods}

A total of 18,491 records from Guzera males and females born between 1987 and 2009 were used in this study. These animals participated in the Programa Guzerá Brasil, coordinated by the Associação Nacional de Criadores e Pesquisadores (ANCP, Brazil). The individuals were managed under an extensive production system based on pasture. Weaning occurred between six and eight months of age. The reproductive management consisted of a mating season lasting 60 to 120 days, using artificial insemination or controlled natural mating.

The performance traits studied were: weaning body weight adjusted to 210 days (W210), at 365 (W365) and 450 (W450) days old; weight gain from birth to weaning (210 days of age; WGBW), from weaning to 365 days of age (WGW365), and from one year to yearling (450 days of age; WGY). The scrotal circumference adjusted at 365 (SC365) and 450 (SC450) days of age were the studied traits related to reproductive performance.

An index, termed "Total Genetic Merit" (TGM), developed by ANCP, Brazil, was employed to select genetically superior males and females since 1999 (Lôbo et al., 2000). This index includes breeding values estimated for the following weighted traits: maternal ability $(0.20)$, weight at $365(0.20)$ and $450(0.20)$ days of age, scrotal circumference at $365(0.10)$ and 450 days of age (0.10), age at first calving (0.15), and gestation period (0.05).

Preliminary analyses were performed for all traits to eliminate inconsistent data. For analysis of fixed effects, animals with no phenotypic data and with no record of sire, dam, and date of birth were excluded. The fixed effects considered in the model were defined by a least square analysis, using the GLM procedure in the SAS software (Statistical Analysis System, version 9.3). Birth season was defined as rainy season for animals born between October and March and dry season for animals born between April and September. The contemporary group consisted of animals having the same sex and from the same farm, year, and birth season. Contemporary groups with less than four records were excluded from the data file. The linear and quadratic effects of the covariate age of dam at calving were considered in the analyses for all traits studied, except for WGW365 and WGY. The analysis of variance was performed using the SAS (v. 9.1) GLM procedure to ascertain the distribution of the residues for each variable. Records with standardized residuals greater than 3.5 or lower than -3.5 standard deviations were excluded. The relationship matrix contained 26,160 animals.

Genetic parameters were estimated by the Restricted Maximum Likelihood Method (REML) for two-trait animal models using the WOMBAT software (Meyer, 2007). The maternal genetic effect was considered in the model for WGBW, W210, WGW365, W365, and W450 traits.

R. Bras. Zootec., 48:e20180034, 2019 
The statistical models proposed for the traits studied are described below:

$$
\begin{array}{r}
y=X \beta+Z a+e \text { and } \\
y=X \beta+Z a+W m+e,
\end{array}
$$

in which $y$ is the vector of records for each trait, $X$ is the incidence matrix for fixed effects, $\beta$ is the fixed effects vector (contemporary group), $Z$ is the incidence matrix relating records to animal additive direct genetic effects, $W$ is the incidence matrix for maternal genetic effects, $a$ is the vector for animal additive direct genetic effects, $m$ is the vector for maternal genetic effects, and $e$ is the random residual effects vector.

The variance and covariance structure of random effects in the multitrait animal model, such as the expected values for $y_{1}$ to $y_{\mathrm{n}}$ are $X_{1} b_{1}$ to $X_{\mathrm{n}} b_{\mathrm{n}^{\prime}}$, respectively, and are presented as follows:

$$
\operatorname{Var}\left[\begin{array}{c}
a \\
a_{2} \\
a_{n} \\
\vdots \\
e_{1} \\
e_{2} \\
\vdots \\
e_{n}
\end{array}\right]=\left[\begin{array}{cccccccc}
A \sigma_{a_{1}}^{2} & \sigma_{a_{1} a_{n}} & \ldots & \sigma_{a_{1} a_{n}} & 0 & 0 & 0 & 0 \\
\sigma_{a_{1} a_{2}} & A \sigma_{a_{2}}^{2} & \ldots & \sigma_{a_{2} a_{n}} & 0 & 0 & 0 & 0 \\
\vdots & \vdots & \ddots & \vdots & 0 & 0 & 0 & 0 \\
\sigma_{a_{1} a_{n}} & \sigma_{a_{2} a_{n}} & \ldots & A \sigma_{a_{n}}^{2} & 0 & 0 & 0 & 0 \\
0 & 0 & 0 & 0 & I \sigma_{e_{1}}^{2} & \sigma_{e_{1} e_{n}} & \ldots & \sigma_{e_{1} e_{n}} \\
0 & 0 & 0 & 0 & \sigma_{e_{1} e_{2}} & I \sigma_{e_{2}}^{2} & \ldots & \sigma_{e_{2} e_{n}} \\
0 & 0 & 0 & 0 & \vdots & \vdots & \ddots & \vdots \\
0 & 0 & 0 & 0 & \sigma_{e_{1} e_{n}} & \sigma_{e_{2} e_{n}} & \ldots & I \sigma_{e_{n}}^{2}
\end{array}\right]
$$

in which $\sigma_{a_{1}}^{2}$ to $\sigma_{a_{n}}^{2}$ are the direct additive genetic effects variances, $\sigma_{e_{1}}^{2}$ to $\sigma_{e_{n}}^{2}$ are the residual variances, $\sigma_{a_{1} a_{2}}$ to $\sigma_{a_{n} a_{n-1}}$ are the additive genetic covariances between traits, $\sigma_{e_{1} e_{2}}$ to $\sigma_{e_{n} e_{n-1}}$ are the residual covariances between traits, and $A$ and $I$ are the relationship matrix and identity matrix, respectively.

Genetic trends for performance traits studied were obtained from the linear regression analysis of mean breeding values according to birth year (1984 to 2009). The t statistic was used to verify the null hypothesis that the regression coefficient was zero, at the $5 \%$ significance level. Genetic trends for SC365 and SC450 were described by Grupioni et al. (2015).

The additive genetic values predicted for the studied traits were used to perform the PCC using the STATISTICA8 software (Statistica 8.0, Statsoft, Inc., Oklahoma, USA). The main purpose of this analysis was to reduce the dimension of the genetic correlation matrix to indicate which traits should be used as selection criteria.

The principal components are orthogonal latent variables consisting of linear combinations of variables (in this case, breeding values for the traits studied). By definition, the first principal component explained most of the total genetic variance, the second principal component explained the second largest portion of the total genetic variability not correlated with the first principal component, and so on, until all the variance has been explained. In a dataset with $p$ variables, the principal component $i$ (PCi) is given by:

$$
P C_{i}=a_{i 1} X_{1}+a_{i 2} X_{2}+\ldots+a_{i j} X_{j}
$$

in which $i=1,2, \ldots, p$ and $\mathrm{j}=1,2, \ldots, p,=j$-th standardized coefficient in the $j$-th variable of the $i$-th principal component; and $X j=j$-th value of the original variable. The standardized coefficients were calculated by:

$$
a_{i j}=\frac{\text { eigenvector }_{i j}}{\sqrt{\text { eigenvalue }_{j}}}
$$

in which $a_{i j}=$ standardized coefficient of genetic values of the $i$-th variable in the $j$-th principal component. 
The number of principal components was chosen based on the Kaiser (1960) criteria, in which only the principal components with eigenvalues greater than 1 explained the most important part of the additive genetic covariance matrix.

\section{Results}

The descriptive statistics for performance and reproductive traits obtained in this study are presented in Table 1 . The heritability estimates obtained in this work from the two-trait analysis (Table 2) ranged from 0.10 (WGY) to 0.41 (W450 and SC450). Maternal heritability estimates were $0.01(0.02)$ for WGBW, 0.06 (0.02) for W210, 0.06 (0.03) for WGW365, 0.04 (0.02) for W365, and 0.02 (0.02) for W450. Genetic correlations among W210, W365, and W450 were positive and high, ranging from 0.91 to 0.97 (Table 2). Weight gains at different ages were positively genetically correlated, ranging from 0.34 to 0.65 . The maternal heritability estimates found for W210, W365, W450, WGBW, and WGW365 were of low magnitude, ranging from $0.01(0.02)$ to $0.06(0.02)$ (Table 2).

The genetic correlation between SC365 and SC450 was positive and favorable (Table 2). Body weights and scrotal circumferences measured at different ages showed positive and favorable genetic correlation

Table 1 - Number of animals (N), mean (M), coefficient of variation (CV\%), and minimum (Min) and maximum (Max) values observed for productive and reproductive traits in Guzera beef cattle

\begin{tabular}{lccccc}
\hline Trait & $\mathrm{N}$ & $\mathrm{M}$ & $\mathrm{CV}(\%)$ & Min & Max \\
\hline W210 (kg) & 9,047 & 120.92 & 19.05 & 47 & 203 \\
W365 (kg) & 4,865 & 241.21 & 23.16 & 104 & 497 \\
W450 (kg) & 6,718 & 278.78 & 64.03 & 130 & 559 \\
WGBW (kg) & 5,044 & 146.89 & 23.59 & 51 & 290 \\
WGW365 (kg) & 6,437 & 62.49 & 56.74 & -66 & 209 \\
WGY (kg) & 6,907 & 36.53 & 58.74 & -50 & 117 \\
SC365 (cm) & 1,773 & 20.82 & 12.38 & 144 & 299 \\
SC450 (cm) & 2,091 & 23.26 & 15.07 & 142 & 360 \\
\hline
\end{tabular}

Weight at 210 days old (W210), year (W365), and yearling (W450); weight gain from birth to weaning (WGBW), from weaning to 365 days old (WGW365), and from one year to yearling (WGY); and scrotal circumference at 365 (SC365) and 450 (SC450) days old.

Table 2 - Direct heritability estimates (diagonal) and maternal $\left({ }^{*}\right)$, standard errors (within parenthesis), genetic (above diagonal), and environmental (bellow diagonal) correlations observed in final data from two-trait analyses for productive and reproductive traits studied in Guzera beef cattle

\begin{tabular}{|c|c|c|c|c|c|c|c|c|}
\hline Trait & W210 & W365 & W450 & WGBW & WGW365 & WGY & SC365 & SC450 \\
\hline W210 (kg) & $\begin{array}{c}0.30(0.05) \\
0.06(0.02)^{*}\end{array}$ & $0.95(0.03)$ & $0.91(0.04)$ & $0.63(0.12)$ & $0.98(0.00)$ & $0.28(0.15)$ & $0.78(0.08)$ & $0.65(0.09)$ \\
\hline W365 (kg) & $0.59(0.02)$ & $\begin{array}{c}0.40(0.05) \\
0.04(0.02)^{*}\end{array}$ & $0.97(0.01)$ & $0.91(0.04)$ & $0.91(0.04)$ & $0.34(0.12)$ & $0.72(0.09)$ & $0.51(0.09)$ \\
\hline W450 (kg) & $0.54(0.03)$ & $0.89(0.01)$ & $\begin{array}{c}0.41(0.05) \\
0.02(0.02)^{*}\end{array}$ & $0.86(0.05)$ & $0.94(0.03)$ & $0.66(0.09)$ & $0.74(0.08)$ & $0.66(0.08)$ \\
\hline WGBW (kg) & $0.14(0.04)$ & $0.68(0.02)$ & $0.57(0.03)$ & $\begin{array}{c}0.19(0.04) \\
0.01(0.02)^{*}\end{array}$ & $0.65(0.13)$ & $0.34(0.15)$ & $0.64(0.13)$ & $0.60(0.12)$ \\
\hline WGW365 (kg) & $0.10(0.00)$ & $0.55(0.03)$ & $0.52(0.03)$ & $0.13(0.05)$ & $\begin{array}{c}0.33(0.06) \\
0.06(0.03)^{*}\end{array}$ & $0.57(0.14)$ & $0.86(0.08)$ & $0.79(0.08)$ \\
\hline WGY (kg) & $0.05(0.03)$ & $0.03(0.03)$ & $0.44(0.02)$ & $0.01(0.03)$ & $0.03(0.04)$ & $\begin{array}{c}0.10(0.02) \\
-\end{array}$ & $0.14(0.18)$ & $0.06(0.17)$ \\
\hline SC365 (cm) & $0.36(0.05)$ & $0.51(0.05)$ & $0.57(0.04)$ & $0.28(0.05)$ & $0.29(0.07)$ & $-0.05(0.04)$ & $\begin{array}{c}0.33(0.07) \\
-\end{array}$ & $0.90(0.04)$ \\
\hline $\mathrm{SC} 450(\mathrm{~cm})$ & $0.36(0.05)$ & $0.55(0.05)$ & $0.58(0.05)$ & $0.18(0.05)$ & $0.32(0.06)$ & $0.20(0.04)$ & $0.70(0.03)$ & $\begin{array}{c}0.41(0.07) \\
-\end{array}$ \\
\hline
\end{tabular}

Weight at 210 days old (W210), year (W365), and yearling (W450); weight gain from birth to weaning (WGBW), from weaning to 365 days old (WGW365), and from one year to yearling (WGY); and scrotal circumference at 365 (SC365) and 450 (SC450) days old. 
ranging from 0.51 to 0.78 (Table 2). Genetic correlations between scrotal circumferences and weight gains measured at different ages ranged from 0.06 (SC450 with WGY) to 0.86 (SC365 with WGW365). Genetic correlations between weights and weight gains measured at different ages ranged from 0.28 (W210 with WGY) to 0.98 (W210 with WGW365).

The regression coefficients obtained from the linear regression analysis of mean predicted breeding values based on animal birth year were significant $(\mathrm{P}<0.0001)$ for all traits studied (Figures $1 \mathrm{~A}$ to $1 \mathrm{E})$, except for WGY. Genetic trends for WGBW, W210, WGW365, W365, and W450 indicated significant linear increases $(\mathrm{P}<0.001)$ in additive direct breeding values equal to $0.42,0.50,0.25,0.79$, and $0.81 \mathrm{~kg}$ per birth year, respectively, from 1984 to 2009.

According to Kaiser (1960) criteria, the two principal components that explained 55.15 and $13.07 \%$ of the breeding value variance were chosen from the eight evaluated traits, totaling $68.22 \%$ of the total genetic additive variance (Table 3).
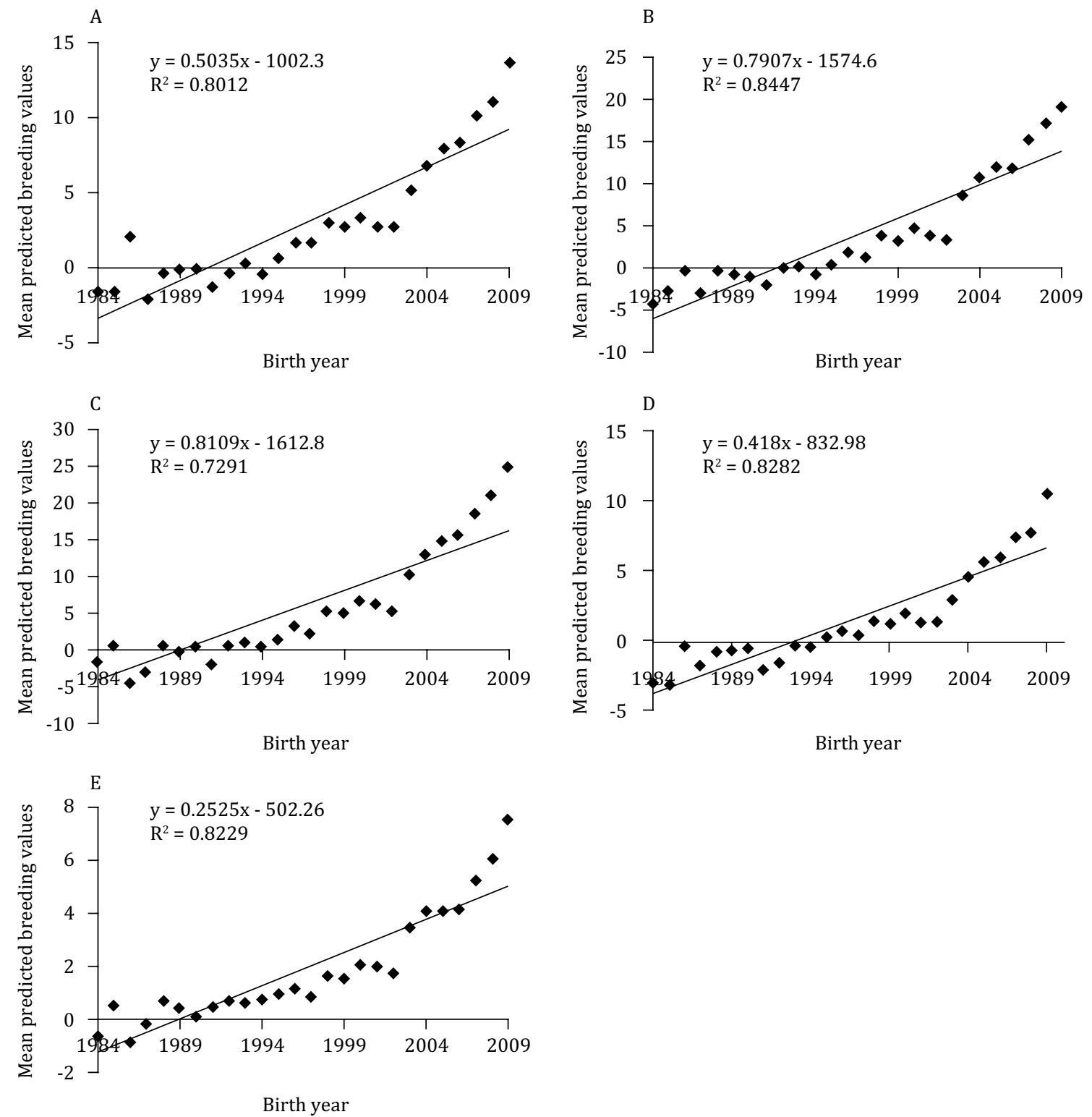

The regression coefficient was significantly $(\mathrm{P}<0.001)$ different from zero at $\mathrm{t}$ test.

$\mathrm{R}^{2}$ - coefficient of determination; weight at 210 days old (W210), year (W365), and yearling (W450); weight gain from birth to weaning (WGBW), and from weaning to 365 days old (WGW365).

Figure 1 - Mean predicted breeding values variation for the traits W210 (A), W365 (B), W450 (C), WGBW (D), and WGW365 (E) from 1984 to 2009. 
Table 3 - Eigenvalues, total variance percentage explained in each principal component (PC1 and PC2), and correlation of the variables in each principal component

\begin{tabular}{lccc}
\hline Principal component & Eigenvalue & Total variance (\%) & Acumulated variance (\%) \\
\hline PC1 & 4.4120 & 55.15 & 55.15 \\
PC2 & 1.0459 & 13.07 & 68.22 \\
\hline
\end{tabular}

\section{Discussion}

Weaning weight adjusted to 210 days of age presented a lower mean $(120.92 \mathrm{~kg})$ than that found by Mucari and Oliveira (2003) in Guzera cattle. Several authors observed means higher than those obtained in this study (Table 1) for weaning weight adjusted to 205, 240, or 270 days of age (Pereira et al., 2001; Yokoo et al., 2007; Boligon et al., 2010a; 2011).

The mean found in this study (241.21 kg) for W365 was higher than values reported by Mucari and Oliveira (2003) for Guzera beef cattle and the one reported by Boligon et al. (2010a) for Nelore cattle. The mean for W450 obtained in this work for Guzera was similar to values reported by Pelicioni et al. (2003), Yokoo et al. (2007), and Boligon et al. (2011) in Nelore cattle. Mucari and Oliveira (2003) found lower means for Guzera cattle. Results observed for the Nelore breed can be considered in comparison with those obtained for Guzera, considering the same Indian origin of both breeds.

The mean obtained for WGBW was similar to the results found in Nelore beef cattle (Sarmento et al., 2003; Boligon et al., 2010b). Weight gain from weaning to 365 days of age had a higher mean $(62.49 \mathrm{~kg})$ than those found in the literature (Sarmento et al., 2003; Boligon et al., 2010a). Weight gain from one year to yearling had a lower mean (36.53 kg) compared with those obtained by Sarmento et al. (2003) and Boligon et al. (2010a) in Nelore cattle. However, the same authors worked with weight gain from one year to 550 days of age. Most of the mentioned authors performed studies in Nelore and adjusted the weight gain for different days of what was considered for this study, which could lead to this change. It could also be due to the origin of the data or even the amount of animals for this trait.

The mean for SC365 was similar $(20.82 \mathrm{~cm})$ to those found in Nelore by Yokoo et al. (2007) and Boligon et al. (2010b, 2011) and higher than those observed in Guzera cattle by Torres-Júnior and Henry (2005) and the one observed by Frizzas et al. (2009) in Nelore beef cattle. For SC450, the mean estimated in this study was higher $(23.26 \mathrm{~cm})$ than that presented by Torres-Júnior and Henry (2005) and Frizzas et al. (2009) and lower than that measured by Yokoo et al. (2007) and Boligon et al. (2010b) in Nelore cattle.

The large variation of the mean (Table 1) observed in this study for productive and scrotal circumference traits was expected. Beef cattle management is extensive, and different nutrition and environmental conditions in each region of the country affect growth and weight gain from animals, as related by Grossi et al. (2009). The minimum values observed for weight gain from weaning to one year and from one year to yearling were negative, indicating there was loss of weight for some animals during these periods. These results indicate that the definition of a breeding season based on nutritional requirements of cows to nutrient availability according to the season of the year may not have been successfully performed in some herds, resulting in animal births outside the favorable season (second half of the year), damaging beef production.

Genetic evaluations of beef cattle in Brazil usually contemplate productive traits, since they are easy to measure and interpret and present heritability estimates from moderate to high magnitudes, indicating that selection may result in genetic progress (Boligon et al., 2009). The heritability estimates found in this study were low for W210 and WGW365, moderate for W210 and WGW365, and high for W365 and W450. Therefore, selection based on body weights (W365 and W450) may be more effective compared with selection based on weight gain, because they presented highest heritability estimates and positive and favorable genetic correlations with the other traits studied (Table 2). The genetic correlations among weight gains at different ages in Nelore cattle reported by Boligon et al. $(2009,2010 \mathrm{~b})$ were 
similar to those observed in this study. Mucari and Oliveira (2003) estimated genetic correlations of similar magnitudes for the performance traits in Guzera cattle.

The heritability estimates reported in literature for performance traits have ranged from 0.14 to 0.35 for W210 (Pimenta Filho et al., 2001), from 0.08 to 0.45 for W365 (Mucari and Oliveira et al., 2003; Souza et al., 2004), and from 0.13 to 0.46 for W550 (Pimenta Filho et al., 2001; Mucari and Oliveira et al., 2003) in Guzera beef cattle. Malhado et al. (2002) estimated genetic correlations of 0.75 between weaning weight adjusted to 205 days of age (W205) and W365, 0.61 between W205 and W550, and 0.65 between W365 and W550 in Guzera beef cattle.

The lower magnitude from WGY and WGBW heritability estimates (Table 2) indicated that a large part of the expression of these traits was caused by non-additive genetic and environmental effects. Selection based on these traits might not be very efficient, because they may respond only slowly to the direct selection process. Among weight gain traits, WGW365 should be the most appropriate trait to be used as selection criteria. A higher proportion of phenotypic variance attributed to additive effects of genes for WGW365 compared with WGBW and WGY results in a higher improvement in genetic gain for WGW365.

Paneto et al. (2002), Sarmento et al. (2003), and Boligon et al. (2010b) found heritability estimates for WGY ranging from 0.21 to 0.25 in Nelore cattle, higher than that estimated in this study (0.10). Yokoo (2007) observed a heritability coefficient estimate of 0.40 for W450 in Nelore beef cattle, similar to the estimate of this study (Table 2).

According to Meyer et al. (1993), traits measured until weaning are influenced by maternal effects. In this study, it was evidenced that the traits measured until weaning, as well as the measures after weaning, were little influenced by maternal effects. Thus, little or no genetic progress is expected due to selection for maternal ability in Guzera beef cattle.

Scrotal circumference is one of the most important reproductive traits used to compose selection indexes in Brazil. Scrotal circumference is an easy trait to measure and has moderate to the high magnitude of heritability estimates (Gressler et al., 2000; Fridrich et al., 2005; Eler et al., 2006; Boligon et al., 2010b). Thus, scrotal circumference presents favorable genetic correlations between semen quantity and quality (Latif et al., 2009), age at puberty in females (Santana et al., 2015), and ponderal development (Ortiz Peña et al., 2001; Brito et al., 2003).

Heritability estimates for SC365 and SC450 were described by Frizzas et al. (2009), Boligon et al. (2010b), and Boligon et al. (2011) and ranged from 0.29 to 0.41 for SC365 and from 0.42 to 0.44 for SC450 in Nelore cattle. Torres-Júnior and Henry (2005) stated that SC presents favorable genetic correlation with body weight in Guzera animals. Positive genetic correlations among SC, weights, and weight gains at different ages have been described in different studies (Frizzas et al., 2009; Boligon et al., 2010b; Raidan et al., 2017), indicating that these traits are determined, in large proportion, by the action of the same additive genes. The selection for higher scrotal circumferences would lead to increased performance traits.

The heritability coefficient for SC450 was higher than that observed for SC365 (Table 2). Yokoo et al. (2007) observed similar results for SC365 and SC450 and suggested that heritability estimates for SC365 were lower than SC450, because few animals entered puberty at 365 days of age.

Frizzas et al. (2009) and Boligon et al. (2010a, 2011) also found positive and favorable genetic correlations between scrotal circumferences measured at different ages in Nelore beef cattle. The favorable and positive genetic correlation between SC365 and SC450 $(0.90 \pm 0.04)$ indicated that animals with a higher scrotal circumference at one year also had a higher scrotal circumference as a yearling. This result suggests that the use of SC365 as a selection criterion could increase genetic improvement, because it becomes possible to select younger animals. However, Grupioni et al. (2015) reported negative and favorable genetic correlations between SC365 and SC450 with age at first calving in the same population of Guzera cattle studied in this work, indicating that selection for scrotal circumferences could result in sexual precocity in females. Yokoo et al. (2007) and Boligon et al. 
(2010a) worked with Nelore cattle and observed genetic correlations similar to those reported in this study. Frizzas et al. (2009) found a positive genetic correlation for these traits, but lower than those reported in this work.

According to Guidolin (2013), it is important to perform measurements of the scrotal circumference at correct ages, because males have a significant growth period of their testicles in early puberty under the action of gonadotropic hormones. Silveira et al. (2004) suggested that the selection of animals with larger scrotal circumference at 12 months of age was associated with the choice of animals with higher levels of gonadotropic hormones in Nelore, and selection at 18 months was related to higher weights and possibly the lower variation in puberty, recommending the selection at 12 months of age. However, Boligon et al. (2010a) evaluated the scrotal circumference at 12 and 18 months of age and concluded that the latter showed higher heritability estimates and, therefore, would present better selection results. The genetic correlation among body weights and scrotal circumference traits found in this work (Table 2) indicated that selection based on scrotal circumference will result in a correlated response in the same direction for growth traits and increase the productivity of herds.

Irano et al. (2016) performed GWAS for indicators of sexual precocity in Nelore cattle and found that windows with great effects for scrotal perimeter and sexual precocity traits were not superimposed, although there is a moderate genetic correlation between these traits in Nelore cattle (Santana et al., 2015). Camargo et al. (2015), studying causal mutations, showed that highly significant SNP for andrological traits were not significant for female reproductive traits. Irano et al. (2016) elaborated three hypotheses to try to explain the association between these traits. The first suggests that the genetic correlation between male and female reproductive traits is due to genes of small effect that affect both traits; the second, that genes can act with a greater effect for one trait and with a smaller effect for another trait; and the third that both previous hypotheses could be occurring.

The genetic gains observed for W365 and W450 traits could be attributed to the direct selection of animals, because these traits are included in the TGM index. The additive direct breeding values observed for W365 and W450 from 1999 to 2009 indicated that the selection process brought significant $(\mathrm{P}<0.05)$ genetic gains over the years for productive performance traits. The positive genetic correlations for WGBW, W210, WGW365, and WGY traits, which are not in the TGM index, allow us to attribute the annual genetic gains to the indirect selection process.

Although the mean genetic value of WGY has not improved over time, a linear increase of WGY mean breeding values is expected in the next generations by selecting for the TGM index, as a result of genetic correlations between WGY and other studied traits included in the TGM index that is undergoing genetic progress.

Two groups of traits are shown in Table 3. The first group is related to body weight and weight gain (Figure 2). The second is related to scrotal circumferences (SC365 and SC450). Body weight and weight gain were strongly associated with principal component 1 (PC1). The SC365 and SC450 were associated with principal component 2 (Figure 2).

The groups of traits studied were not orthogonal to each other. All traits were considerably genetically correlated, and this fact can explain why the two groups of traits were not completely separated. These results suggest that the selection of animals could be made based on two traits (one for each group) instead of all traits. Thus, the genetic gains of the other traits within each group would be in the same direction of the trait chosen as a selection criterion.

Thus, we recommend selecting animals for W365 based on PC1, and SC365 based on PC2. Another implication about the non-orthogonality between the groups of traits is that they could result in correlated responses for all traits, regardless of that chosen as a selection criterion, which is in accordance with the estimates of genetic correlations (Table 2).

R. Bras. Zootec., 48:e20180034, 2019 


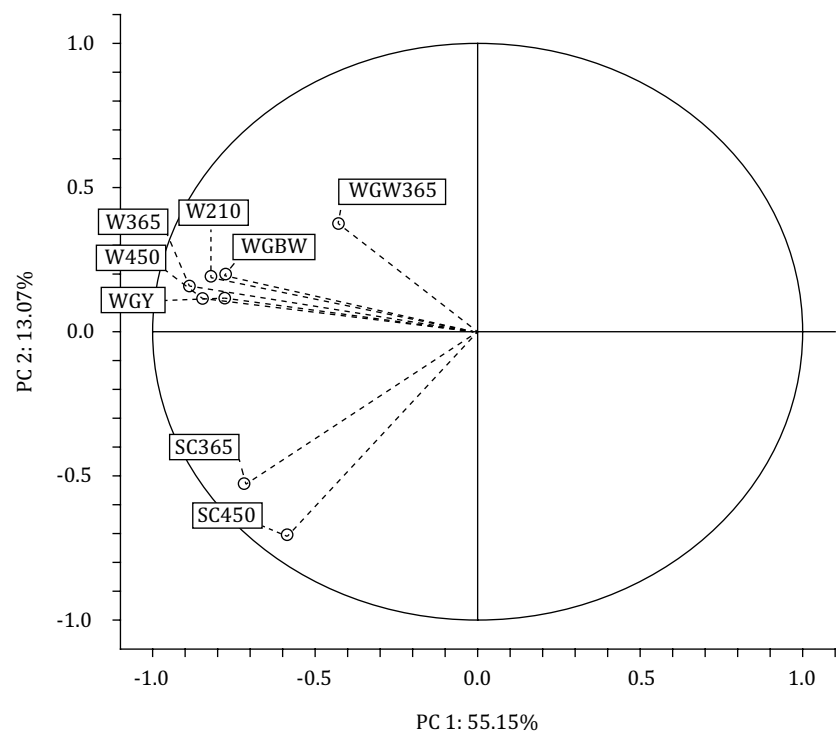

Weight at 210 days old (W210), year (W365), and yearling (W450); weight gain from birth to weaning (WGBW), from weaning to 365 days old (WGW365), and from one year to yearling (WGY); and scrotal circumference at 365 (SC365) and 450 (SC450) days old.

Figure 2 - Two-dimensional graphs from principal component 1 (PC 1) versus 2 (PC 2).

\section{Conclusions}

Body weight at one year of age, yearling weight, and scrotal circumferences traits could be used as selection criteria for improvement of performance and reproduction traits, because they have enough additive genetic components to respond to the selection and belong to the Total Genetic Merit index. Their genetic gains from the selection process will be attributed in the same way in the other studied traits.

\section{Conflict of Interest}

The authors declare no conflict of interest.

\section{Author Contributions}

Conceptualization: R.B. Lôbo and D.P. Munari. Data curation: N.C. Tramonte, N.V. Grupioni and L.A.F. Bezerra. Formal analysis: N.C. Tramonte. Funding acquisition: R.B. Lôbo. Project administration: R.B. Lôbo and D.P. Munari. Supervision: D.P. Munari. Writing-original draft: N.C. Tramonte. Writing-review \& editing: N.V. Grupioni, N.B. Stafuzza, D.G.F. Guidolin, R.P. Savegnago and D.P. Munari.

\section{Acknowledgments}

The authors would like to thank the Fundação de Amparo à Pesquisa do Estado de São Paulo (FAPESP) for the scholarships granted to Nicole Colucci Tramonte (2011/07124-1) and Rodrigo Pelicioni Savegnago (2013/20091-0), and Coordenação de Aperfeiçoamento de Pessoal de Nível Superior (CAPES), for postdoctoral fellowships granted to Natalia Vinhal Grupioni (CAPES/EMBRAPA), Nedenia BonvinoStafuzza (CAPES/PNPD), and Diego Gomes Freire Guidolin. Danísio Prado Munari was granted a productivity research fellowship from Conselho Nacional de Desenvolvimento Científico e Tecnológico (CNPq).

\section{References}

Boligon, A. A.; Albuquerque, L. G.; Mercadante, M. E. Z. and Lôbo, R. B. 2009. Herdabilidades e correlações entre pesos do nascimento à idade adulta em rebanhos da raça Nelore. Revista Brasileira de Zootecnia 38:2320-2326. https://doi.org/10.1590/S1516-35982009001200005 
Boligon, A. A.; Silva, J. A. V.; Sesana, R. C.; Sesana, J. C.; Junqueira, J. B. and Albuquerque, L. G. 2010a. Estimation of genetic parameters for body weights, scrotal circumference, and testicular volume measured at different ages in Nellore cattle. Journal of Animal Science 88:1215-1219. https://doi.org/10.2527/jas.2008-1719

Boligon, A. A.; Albuquerque, L. G.; Mercadante, M. E. Z. and Lôbo, R. B. 2010b. Study of relations among age at first calving, mean weight gains and weights from weaning to maturity in Nellore cattle. Revista Brasileira de Zootecnia 39:746-751. https://doi.org/10.1590/S1516-35982010000400007

Boligon, A. A.; Baldi, F. and Albuquerque, L. G. 2011. Genetic parameters and relationships between growth traits and scrotal circumference measured at different ages in Nellore cattle. Genetics and Molecular Biology 34:225-230. https://doi.org/10.1590/S1415-47572011005000004

Brito, L. F. C.; Silva, A. E. D. F.; Barbosa, R. T.; Unanian, M. M. and Kastelic, J. P. 2003. Effects of scrotal insulation on sperm production, semen quality and testicular echotexture in Bos indicus and Bos indicus x Bos taurus bulls. Animal Reproduction Science 79:1-15. https://doi.org/10.1016/S0378-4320(03)00082-4

Camargo, G. M. F.; Porto-Neto, L. R.; Kelly, M. J.; Bunch, R. J.; McWilliam, S. M.; Tonhati, H.; Lehnert, S. A.; Fortes, M. R. S. and Moore, S. S. 2015. Non-synonymous mutations mapped to chromosome X associated with andrological and growth traits in beef cattle. BMC Genomics 16:384. https://doi.org/10.1186/s12864-015-1595-0

Campêlo, J. E. G.; Lopes, P. S.; Torres, R. A.; Silva, L. O. C.; Euclydes, R. F.; Araújo, C. V. and Pereira, C. S. 2004. Maternal effects on the genetic evaluation of Tabapuã beef cattle. Genetics and Molecular Biology 27:517-521. https://doi.org/10.1590/S1415-47572004000400009

Eler, J. P.; Ferraz, J. B. S.; Balieiro, J. C. C.; Mattos, E. C. and Mourão, G. B. 2006. Genetic correlation between heifer pregnancy and scrotal circumference measured at 15 and 18 months of age in Nellore cattle. Genetics and Molecular Research 5:569-580.

Fridrich, A. B.; Silva, M. A.; Fridrich, D.; Corrêa, G. S. S.; Silva, L. O. C.; Sakaguti, E. S.; Ferreira, I. C. and Valente, B. D. 2005. Interação genótipo $\times$ ambiente e estimativas de parâmetros genéticos de características ponderais de bovinos Tabapuã. Arquivo Brasileiro de Medicina Veterinária e Zootecnia 57:663-672.

Frizzas, O. G.; Grossi, D. A.; Buzanskas, M. E.; Paz, C. C. P.; Bezerra, L. A. F.; Lôbo, R. B.; Oliveira, J. A. and Munari, D. P. 2009. Heritability estimates and genetic correlations for body weight and scrotal circumference adjusted to 12 and 18 months of age for male Nellore cattle. Animal 3:347-351. https://doi.org/10.1017/S175173110800373X

Gressler, S. L.; Bergmann, J. A. G.; Pereira, C. S.; Penna, V. M.; Pereira, J. C. C. and Gressler, M. G. M. 2000. Estudo das associações genéticas entre perímetro escrotal e características reprodutivas de fêmeas Nelore. Revista Brasileira de Zootecnia 29:427-437. https://doi.org/10.1590/S1516-35982000000200016

Grossi, D. A.; Venturini, G. C.; Paz, C. C. P.; Bezerra, L. A. F.; Lôbo, R. B.; Oliveira, J. A. and Munari, D. P. 2009. Genetic associations between age at first calving and heifer body weight and scrotal circumference in Nelore cattle. Journal of Animal Breeding and Genetics 126:387-393. https://doi.org/10.1111/j.1439-0388.2008.00791.x

Grupioni, N. V.; Guidolin, D. G. F.; Venturini, G. C.; Lôbo, R. B. and Munari, D. P. 2015. Parâmetros genéticos e tendências genéticas para características reprodutivas e de crescimento testicular em bovinos Guzerá. Revista Caatinga 28:152-160.

Guidolin, D. G. F. 2013. Estrutura populacional e parâmetros genéticos de uma população de bovinos Guzerá. Tese (D.Sc.). Universidade Estadual Paulista, Jaboticabal.

Irano, N.; Camargo, G. M. F.; Costa, R. B.; Terakado, A. P. N.; Magalhães, A. F. B.; Silva, R. M.; Dias, M. M.; Bignardi, A. B.; Baldi, F.; Carvalheiro, R.; Oliveira, H. N. and Albuquerque, L. G. 2016. Genome-wide association study for indicator traits of sexual precocity in Nellore cattle. PLOS ONE 11(8):e0159502. https://doi.org/10.1371/journal.pone.0159502

IBGE - Instituto Brasileiro de Geografia e Estatística. 2015. Produção da pecuária municipal. Available at: <http://biblioteca.ibge.gov.br/visualizacao/periodicos/84/ppm_2015_v43_br.pdf>. Accessed on: Oct. 24, 2017.

Kaiser, H. F. 1960. The application of electronic computers to factor analysis. Educational and Psychological Measurement 20:141-151. https://doi.org/10.1177/001316446002000116

Latif, M. A.; Ahmed, J. U.; Bhuiyan, M. M. U. and Shamsuddin, M. 2009. Relationship between scrotal circumference and semen parameters in crossbred bulls. Bangladesh Veterinarian 26:61-67. https://doi.org/10.3329/bvet.v26i2.4952

Laureano, M. M. M.; Boligon, A. A.; Costa, R. B.; Forni, S.; Severo, J. L. P. and Albuquerque, L. G. 2011. Estimativas de herdabilidade e tendências genéticas para características de crescimento e reprodutivas em bovinos da raça Nelore. Arquivo Brasileiro de Medicina Veterinária e Zootecnia 63:143-152. https://doi.org/10.1590/S010209352011000100022

Lôbo, R. B.; Bezerra, L. A. F.; Oliveira, H. N.; Garnero, A. V.; Schwengber, E. B. and Marcondes, C. R. 2000. Avaliação genética de animais jovens, touros e matrizes: Sumário 2000. Universidade de São Paulo/GEMAC, Ribeirão Preto.

Malhado, C. H. M.; Souza, J. C.; Silva, L. O. C. and Ferraz Filho, P. B. 2002. Correlações genéticas, fenotípicas e de ambiente entre os pesos de várias idades em bovinos da raça Guzerá no estado de São Paulo. Archives of Veterinary Science 7:71-75. https://doi.org/10.5380/avs.v7i1.3971

Meyer, K.; Carrick, M. J. and Donnelly, B. J. P. 1993. Genetic parameters for growth traits of Australian beef cattle from a multibreed selection experiment. Journal of Animal Science 71:2614-2622. https://doi.org/10.2527/1993.71102614x 
Meyer, K. 2007. WOMBAT - A tool for mixed model analyses in quantitative genetics by restricted maximum likelihood (REML). Journal of Zhejiang University Science B 8:815-821. https://doi.org/10.1631/jzus.2007.B0815

Mucari, T. B. and Oliveira, J. A. 2003. Análise genético-quantitativa de pesos aos 8, 12,18 e 24 meses de idade em um rebanho da raça Guzerá. Revista Brasileira de Zootecnia 32:1604-1613. https://doi.org/10.1590/S1516-35982003000700009

Ortiz Peña, C. D.; Queiroz, S. A. and Fries, L. A. 2001. Comparação entre critérios de seleção de precocidade sexual e a associação destes com características de crescimento em bovinos Nelore. Revista Brasileira de Zootecnia 30:93-100. https://doi.org/10.1590/S1516-35982001000100015

Paneto, J. C. C.; Lemos, D. C.; Bezerra, L. A. F.; Martins Filho, R. and Lôbo, R. B. 2002. Estudo de características quantitativas de crescimento dos 120 aos 550 dias de idade em gado Nelore. Revista Brasileira de Zootecnia 31:668-674. https://doi.org/10.1590/S1516-35982002000300017

Peixoto, M. G. C. D.; Bruneli, F. A. T.; Santos, G. G.; Penna, V. M.; Josahkian, L. A.; Verneque, R. S.; Machado, M. A.; Panetto, J. C. C.; Lôbo, R. B. and Carvalho, M. R. S. 2016. Programa Nacional de Melhoramento do Guzerá para leite: resultados do Teste de Progênie, do Programa de Melhoramento Genético de Zebuínos da ABCZ e do Núcleo MOET. Embrapa Gado de Leite Documentos No. 188. Embrapa Gado de leite, Juiz de Fora, MG, Brazil.

Pelicioni, L. C.; Queiroz, S. A. and Albuquerque, L. G. 2003. Estimativas de parâmetros genéticos para pesos ao nascer e mensais até 450 dias em bovinos Guzerá. Archivo Latinoamericano de Producion Animal 11:34-39.

Pereira, E.; Eler, J. P.; Costa, F. A. A. and Ferraz, J. B. S. 2001. Análise genética da idade ao primeiro parto e do perímetro escrotal em bovinos da raça Nelore. Arquivo Brasileiro de Medicina Veterinária e Zootecnia 53:116-121. https://doi.org/10.1590/S0102-09352001000100019

Pimenta Filho, E. C.; Martins, G. A.; Sarmento, J. L. R.; Ribeiro, M. N. and Martins Filho, R. 2001. Estimativas de herdabilidade de efeitos direto e materno de características de crescimento de bovinos Guzerá, no Estado da Paraíba. Revista Brasileira de Zootecnia 30:1220-1223. https://doi.org/10.1590/S1516-35982001000500013

Raidan, F. S. S.; Tineo, J. S. A.; Moraes, M. M.; Escarce, T. C.; Araújo, A. E. M.; Gomes, M. M. C.; Ventura, H. T. and Toral, F. L. B. 2017. Associations among growth, scrotal circumference, and visual score of beef cattle in performance tests on pasture or in feedlots. Revista Brasileira de Zootecnia 46:309-316. https://doi.org/10.1590/s1806-92902017000400006

Santana, M. L. Jr.; Eler, J. P.; Bignardi, A. B. and Ferraz, J. B. S. 2015. Two-trait random regression model to estimate the genetic association of scrotal circumference with female reproductive performance in Nelore cattle. Theriogenology 83:1534-1540. https://doi.org/10.1016/j.theriogenology.2015.02.003

Sarmento, J. L. R.; Pimenta Filho, E. C.; Ribeiro, M. N. and Martins Filho, R. 2003. Efeitos ambientais e genéticos sobre o ganho em peso diário de bovinos Nelore no Estado da Paraíba. Revista Brasileira de Zootecnia 32:325-330. https://doi.org/10.1590/S1516-35982003000200010

Silveira, J. C.; McManus, C.; Mascioli, A. S.; Silva, L. O. C.; Silveira, A. C.; Garcia, J. A. S. and Louvandini, H. 2004. Fatores ambientais e parâmetros genéticos para características produtivas e reprodutivas em um rebanho Nelore no estado do Mato Grosso do Sul. Revista Brasileira de Zootecnia 33:1432-1444. https://doi.org/10.1590/S1516-35982004000600010

Souza, J. C.; Malhado, C. H. M.; Silva, L. O. C.; Leal, T. L.; Gomes, C. M.; Jacinto, E. J. and Ferraz Filho, P. B. 2004. Parâmetros e tendência genética em bovinos da raça Guzerá na microrregião Mata e Agreste no nordeste do Brasil. Revista Acadêmica: Ciências Agrárias e Ambientais 2:47-52. https://doi.org/10.7213/cienciaanimal.v2i2.15063

Torres-Júnior, J. R. S. and Henry, M. 2005. Sexual development of Guzerat (Bos taurus indicus) bulls raised in a tropical region. Animal Reproduction 2:114-121.

Yokoo, M. J. I.; Albuquerque, L. G.; Lôbo, R. B.; Sainz, R. D.; Carneiro Júnior, J. M.; Bezerra, L. A. F. and Araujo, F. R. C. 2007. Estimativas de parâmetros genéticos para altura do posterior, peso e circunferência escrotal em bovinos da raça Nelore. Revista Brasileira de Zootecnia 36:1761-1768. https://doi.org/10.1590/S1516-35982007000800008 